П. В. Лапін, М. Д. Кацман

Акціонерне товариство «Українська залізниця», Київ, Україна

\title{
ВИКОРИСТАННЯ БЕЗПІЛОТНИХ ЛІТАЛЬНИХ АПАРАТІВ ДЛЯ ОХОРОНИ ВАНТАЖІВ І ОБ'ЄКТІВ НА ЗАЛІЗНИЧНОМУ ТРАНСПОРТІ
}

\begin{abstract}
Анотація. Мета роботи - обгрунтування можливостей повітряного патрулювання об'єктів інфраструктури залізничного транспорту за допомогою безпілотних літальних апаратів (БПЛА). Результати. У статті досліджено можливості застосування безпілотних літальних апаратів для забезпечення охорони залізничної інфраструктури та вантажів. Розкривається зміст використання безпілотних літальних апаратів як системного моніторингу, що включає підсистему управління і підсистему оперативних груп воєнізованої охорони залізничного транспорту. Описана запропонована авторами модель використання безпілотних літальних апаратів, яка заснована на понятті «критичного часу», як різниці між часом безпосереднього втручання зловмисника в залізничну інфраструктуру та часом реагування підрозділів воєнізованої охорони залізниці із використанням безпілотного апарату. Розкривається приклад використання безпілотного літального апарату на конкретній криміногенні ділянці залізниці з використанням запропонованої моделі. Висновок. Підвищення рівня схоронності вантажів, зменшення злочинних посягань на об'єкти інфраструктури залізничного транспорту, а також зниження збитків від крадіжок досягається за рахунок використання нових технологій, таких як БПЛА. Запропонована авторами модель $є$ доступним, простим та зрозумілим інструментом до для реалізації проектів із впровадження моніторингу об'єктів залізничної інфраструктури за допомогою БПЛА.
\end{abstract}

Ключов і слов а: безпілотні літальні апарати, критичний час, воєнізована охорона залізниці, зловмисник, криміногенні ділянки, залізниця, попередження та розкриття злочинів.

\section{Постановка проблеми}

За останні п’ять років ситуація у сфері безпеки на залізничному транспорті значно погіршилася через низку причин об’єктивного характеру. Протиправні дії щодо об’єктів залізничного транспорту, розкрадання вантажів та умисні руйнування і пошкодження залізничної інфраструктури набули серйоних масштабів.

Щорічно фіксується декілька тисяч випадків несанкціонованого втручання на об'єктах залізничної інфраструктури, а сума завданих збитків сягає десятків мільйонів гривень.

Слід зауважити, що ефективність боротьби зі злочинністю характеризується не тільки зменшенням кількості зареєстрованих злочинів, а й рівнем їх попередження та розкриття.

Постійно підвищується професійний рівень та технічне оснащення зловмисників, зростає ступінь протидії розкриттю злочинів.

Одночасно з цим викликає побоювання серйозна завантаженість оперативних груп Національної поліції та воєнізованої охорони на залізничному транспорті, які фізично не можуть обстежити протяжні багатокілометрові ділянки залізничних перегонів.

Все це зумовлює неможливість домогтися максимально ефективного результату із попередження та розкриття злочинів, пов'язаних із втручанням в діяльність об'єктів залізничної інфраструктури $\mathrm{i}$, як наслідок, відбувається збільшення рівня крадіжок майна на залізничному транспорті.

Сказане дає підстави стверджувати про необхідність вдосконалення науково-технічного забезпечення діяльності підрозділів воєнізованої охорони на залізничному транспорті, консолідації їх зусиль i тісної взаємодії між собою в ході реалізації заходів по боротьбі зі розкраданням залізничного майна.
У зв'язку з цим, а також $з$ огляду на особливу значущість часу отримання первинної інформації, одержуваної в результаті втручання в діяльність об'єктів залізничної інфраструктури необхідно приділити увагу розвитку новітніх технологій забезпечення охорони вантажів і об'єктів на залізничному транспорті, зокрема із використанням безпілотних літальних апаратів (БПЛА).

Аналіз останніх досліджень i публікацій в яких започатковано розв'язання даної проблеми. Крім очевидних військових цілей застосування БПЛА, все більший інтерес викликають можливості їх використання в цивільній сфері [1]. Основною цариною застосування БПЛА в мирних цілях $\epsilon$ різноманітні види застосування безпілотної авіації в народному господарстві, в тому числі $[2,3]$ :

моніторинг великих територій і акваторій,

картографія,

аерофотозйомка,

охорона кордонів і берегових ліній,

екологічний моніторинг газо- і нафтопроводів, лісів і водойм,

авіалісоохорона,

пошуково-рятувальні роботи,

авіахімічні роботи,

пошук викрадених транспортних засобів, порушників кордону, браконьєрів тощо.

Метою роботи $є$ обгрунтування можливостей повітряного патрулювання об'єктів інфраструктури залізничного транспорту за допомогою БПЛА.

\section{Виклад основного матеріалу дослідження}

У 2013 році німецький державний залізничний оператор «Deutsche Bahn» розпочав використовувати безпілотні літаки для боротьби з графітистами, чия робота щорічно наносить залізниці збитків на суму 6,7 млн. Євро [4]. 
У 2014 році започатковано пілотний проект із застосування БПЛА для охорони вантажів і об'єктів польським вантажним перевізником «РКР Cargo» [5]. У жовтні 2015 року «BNSF Railway», друга за величиною вантажна залізнична мережа в США 3 32500 милями залізничних колій, розпочала використання БПЛА для моніторингу 140-ти кілометрової ділянки колії у штаті Нью-Мексико [6].

Вивченню перспектив використання БПЛА при ліквідації наслідків залізничних транспортних подій присвячена робота українських вчених [7].

Отже, залізничний транспорт - перспективна сфера застосування нових можливостей, що надаються БПЛА.

Однак, передчасно думати, що настільки широке поле застосування БПЛА повністю відкрито, варто лише розробити апарати та обладнання, здатні виконувати завдання із моніторингу протяжних залізничних перегонів. Освоєння БПЛА для використання на залізничному транспорті вимагає цілого ряду специфічних витрат часу і коштів, обумовлених принциповою новизною відповідних напрямів роботи.

Перш за все, необхідний розвиток нормативноправової бази, що регламентує застосування БПЛА на залізничному транспорті, забезпечення необхідного рівня безпеки польотів, адже від загального обсягу перевезень вантажів залізничним транспортом близько $15 \%$ становлять небезпечні вантажі (вибухонебезпечні, пожежонебезпечні, хімічні та інші речовини) [8].

Слід підкреслити, що повітряне патрулювання лише забезпечує оперативне виявлення несанкціонованого втручання на об'єктах залізничної інфраструктури і ї локалізацію. Але використовувати отриману при цьому в реальному часі інформацію повинні оперативні групи Національної поліції та воєнізованої охорони залізниці, від ефективності роботи яких залежить кінцевий результат повітряного моніторингу - затримання правопорушника та відшкодування збитків, завданих інфраструктурі залізничного транспорту.

Саме по собі повітряне патрулювання із необмеженим часом обльоту $\left(t_{\text {патрул. }}\right)$ криміногенних ділянок залізничних перегонів (тобто, при $t_{\text {патрул. }} \rightarrow \infty$ ) не впливає на відшкодування зловмисником збитків від несанкціонованого втручання, а отже не може вважатися ефективним.

Тому система повітряного моніторингу об'єктів інфраструктури залізничного транспорту за допомогою БПЛА повинна складатися не тільки із підсистеми управління, підсистеми БПЛА, але й підсистеми оперативних груп воєнізованої охорони, а надійність повітряного моніторингу об'єктів залізничної інфраструктури повинна визначатися досконалістю всіх його підсистем (рис. 1).

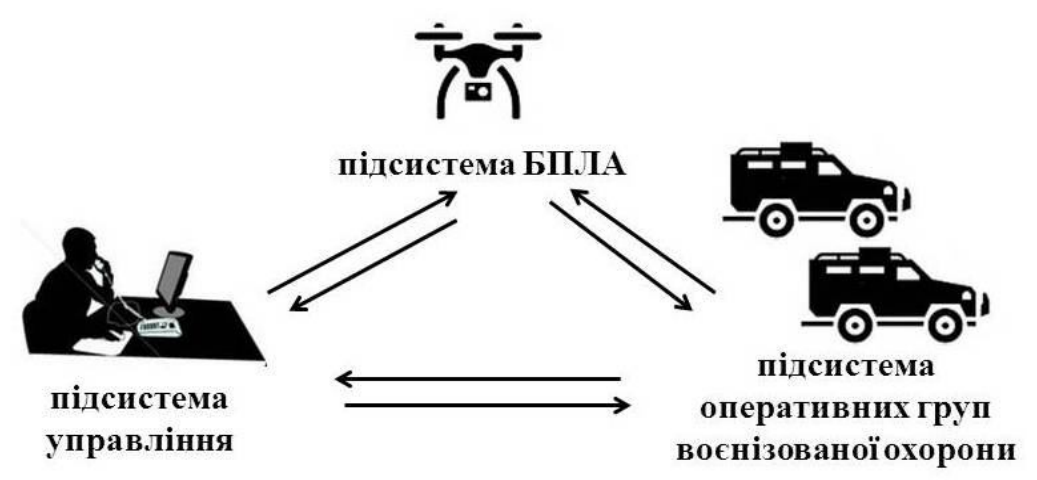

Рис. 1. Система повітряного моніторингу об'єктів інфраструктури залізничного транспорту за допомогою БПЛА

Діяльність системи повітряного моніторингу об'єктів інфраструктури залізничного транспорту за допомогою БПЛА може здійснюватись у тому числі і на основі певних математичних моделей, що відображають динаміку оперативної роботи з протидії у втручання в діяльність об'єктів залізничної інфраструктури.

Авторами пропонується модель, яка грунтується на понятті «критичний час» $\left(t_{k p .}\right)$.

«Критичний час» у даній моделі - це різниця між часом, протягом якого зловмисниками безпосередньо здійснюється несанкціоноване втручання в діяльність об'єктів залізничної інфраструктури на місці $\left(t_{\text {втруч. }}\right)$ і часом реагування системи повітряного моніторингу об'єктів інфраструктури залізничного транспорту за допомогою БПЛА $\left(t_{\text {peaz. }}\right)$.

$$
t_{\text {кp. }}=t_{\text {вmpyч. }}-t_{\text {peaz }} .
$$

Очевидно, що ефективною система повітряного моніторингу об'єктів інфраструктури залізничного транспорту за допомогою БПЛА може бути лише при значеннях $t_{k p} \geq 0$.

Час реагування $\left(t_{\text {реаз }}\right)$ залежить від певної кількості чинників, зокрема, від тривалості процесу ідентифікації загрози інфраструктурі залізничного транспорту оператором БПЛА $\left(t_{\text {iдентиф. }}\right)$, тривалості процесу повідомлення доступними засобами зв'язку про загрозу несанкціонованого втручання на об'єкт залізничної інфраструктури $\left(t_{\text {повідомл. }}\right)$, тривалості процесу визначення сил і засобів для оперативного перехвату об'єкту, що загрожує інфраструктурі залізничного транспорту, формування і передачі наказу на виїзд оперативним групам воєнізованої охорони $\left(\mathrm{t}_{\text {наказ }}\right)$, тривалості збору і виїзду оперативних груп воєнізованої охорони по тривозі $\left(t_{3 б о р \nu ~}\right)$, часу прямування оперативних підрозділів воєнізованої охорони 
до місця несанкціонованого втручання на об'єкт залізничної інфраструктури, виявленого БПЛА $\left(t_{\text {ррямуув. }}\right)$.

Таким чином, сумарний час реагування системи при несанкціонованому втручанні на об'єкт залізничної інфраструктури визначається як:

$$
t_{\text {реаг. }}=t_{\text {iдентиф. }}+t_{\text {повідомл. }}+t_{\text {наказ }}+t_{\text {збору }}+t_{\text {прямув. }}
$$

Отже, суттю запропонованої моделі є те, що в ній розглядаються два протилежні процеси, які розвиваються у часі лінійно. 3 них перший - це процес фізичної втрати майна внаслідок несанкціонованого втручання на об'єкт залізничної інфраструктури, а другий - це процес припинення цих втрат, завдяки заходам повітряного спостереження та діяльності оперативних груп воєнізованої охорони.

Практична цінність запропонованої формули (1) полягає в тому, що на підставі конкретних часових характеристик діяльності системи повітряного патрулювання об'єктів залізничної інфраструктури можна визначити оптимальну чисельність оперативних груп воєнізованої охорони залізниці для патру- лювання конкретної криміногенної ділянки залізниці.

Припустимо, що $l$ - відстань від місця дислокації оперативних підрозділів воєнізованої охорони залізниці до місця несанкціонованого втручання на об’єкт залізничної інфраструктури, км; 40 км/год. середня швидкість руху автомобіля оперативної групи воєнізованої охорони на пересічній місцевостi.

Отже, час прямування оперативних підрозділів воєнізованої охорони до місця несанкціонованого втручання на об'єкт залізничної інфраструктури, виявленого БПЛА $\left(t_{\text {прямув. }}\right)$ розраховується за формулою:

$$
t_{\text {прямув. }}=l / 40_{\text {км/год }}
$$

Припустимо, що значення перемінних, які входять до формули (2), а саме $t_{\text {ідентиф. }}, t_{\text {повідомл, }}, t_{\text {наказ }}$,

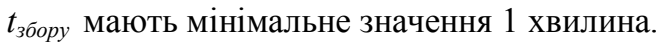

Підставимо ці значення у формулу (2), проаналізуємо ці залежності та покажемо їх значення в табл. 1 .

Таблиия 1 - Розрахунок часу реагування оперативних груп воснізованої охорони

\begin{tabular}{|c|c|c|c|c|c|c|}
\hline Відстань $(l)$, км & $t_{\text {ideнт.xв. }}$ & $t_{\text {повідом. хв. }}$ & $t_{\text {наказ, хв. }}$ & $t_{3 б о p y, x \varepsilon .}$ & $t_{\text {прямув } \times 6 .}$ & $t_{\text {peaz. x6. }}$ \\
\hline 1 & 1 & 1 & 1 & 1 & 1,5 & 5,5 \\
\hline 3 & 1 & 1 & 1 & 1 & 4,5 & 8,5 \\
\hline 5 & 1 & 1 & 1 & 1 & 7,5 & 11,5 \\
\hline 7 & 1 & 1 & 1 & 1 & 10,5 & 14,5 \\
\hline 10 & 1 & 1 & 1 & 1 & 15 & 19 \\
\hline
\end{tabular}
в залежності від місця їх дислокації

Враховуючи обгрунтоване припущення, що середній час протягом якого зловмисниками здійснюється несанкціоноване втручання в діяльність об'єктів залізничної інфраструктури $t_{\text {втрvч. }}=15$ хвилин, то оптимальна чисельність оперативних груп воєнізованої охорони для патрулювання складає 1 група на кожні 5-7 км конкретної криміногенної ділянки залізниці.

Саме така кількість оперативних дозволить мати значення $t_{k p} \geq 0$.

Визначимо оптимальну кількість БПЛА, що необхідна для патрулювання певної криміногенної ділянки залізниці.

Враховуючи значення $\mathrm{t}_{\text {втруч. }}=15$ хвилин, інтенсивність спостереження за кожною точкою криміногенної ділянки залізниці також повинна складати 15 хвилин, тобто щонайменше кожні 15 хвилин кожна ділянка залізничної колії повинна потрапити в поле зору камери БПЛА.

Розрахуємо оптимальну кількість БПЛА для патрулювання ділянки ст.Біличі - ст.Буча регіональної філії «Південно-Західна залізниця» загальною протяжністю 12 км.

Для розрахунку повітряного моніторингу об'єктів в реальному часі візьмемо полікоптер, який має робочу швидкість 30 км/год.
Припустимо, що криміногенна ділянка залізничної колії протяжністю $L$ км патрулюється силами авіапарку, що складається $3 n$ однотипних БПЛА.

Якщо середня швидкість польоту в режимі патрулювання дорівнює V км/год, то при повітряному патрулюванні ділянки $L$ за $h$ льотних годин парк БПЛА пройде загальну відстань, рівну $n \times V \times h$ км.

Таким чином, в середньому буде здійснено $(n \times V \times h) / L$ обльотів криміногенної ділянки, а періодичність обльоту $\left(T_{\text {обльотv }}\right)$ кожної точки криміногенної ділянки, можна знайти за формулою (4):

$$
T_{\text {обльоту }}=L /(n \times V)
$$

звідки,

$$
n=L /\left(T_{\text {обльоту }} \times V\right)
$$

Підставивши числові значення протяжності ділянки ст.Біличі - ст.Буча регіональної філії «Південно-Західна залізниця» та характеристик полікоптеру у формулу (5) визначимо, що для патрулювання цієї ділянки з інтенсивністю повітряного обстеження кожної точки 15 хвилин необхідно 1,6 (зрозуміло, що результат округляється до найближчого цілого числа 2) БПЛА типу полікоптер зі швидкістю 30 км/год. 
3 формули (5) також випливає висновок, що оптимальна кількість БПЛА необхідна для патрулювання криміногенної ділянки залізниці, як і слід було очікувати, прямо пропорційна довжині цієї ділянки.

3 економічної точки зору патрулювання об’єктів залізничної інфраструктури має важливу характерну особливість. 3 одного боку, чим більше здійснюється польотів, тим більші витрати на організацію патрулювання. 3 іншого - підвищення інтенсивності патрулювання особливо криміногенних ділянок залізничних перегонів може сприяти скороченню очікуваних збитків від розкрадання залізничної інфраструктури [9].

Зрозуміло, що організація процесу патрулювання об'єктів інфраструктури залізничного транспорту за допомогою БПЛА в реальності вимагає більш детального обліку неоднорідності ділянок через які проходять залізничної колії, оптимізації маршрутів польоту, розташування та оснащення оперативних груп воєнізованої охорони, врахування погодних умов тощо.

Крім того, всі складові запропонованої моделі містять цілий ряд істотних спрощень, які можна зняти після проведення пілотного проекту із використання БПЛА на залізничному транспорті.

\section{Висновки}

Підвищення рівня схоронності вантажів, зменшення злочинних посягань на об'єкти інфраструктури залізничного транспорту, а також зниження збитків від крадіжок досягається за рахунок використання нових технологій, таких як безпілотні літальні апарати.

Запропонована авторами модель є доступним, простим та зрозумілим інструментом до для реалізації проектів із впровадження моніторингу об'єктів залізничної інфраструктури за допомогою БПЛА.

\section{СПИСОК ЛІТЕРАТУРИ}

1. Фещенко А. Л. Напрями використання світового досвіду застосування безпілотних літальних апаратів в інтересах Збройних Сил України / А. Л. Фещенко // Труди академії. - 2008. - № 90. - С. 89-91

2. Купріянова В. С. Стан та перспективи розвитку безпілотних літальних апаратів в Україні / В. С. Купріянова, I. Ю. Матюшенко // Вісник економіки транспорту і промисловості. - 2015. - Вип. 50. - С. 334-340

3. Никитова А.С. БПЛА в топливно-энергетическом комплексе и экологическом мониторинге / Никитова А.С., Клочков В.В. // Энергия: экономика, техника, экология - 2013. - №2. - С. 34-41

4. “German railways to test anti-graffiti drones" ВBC News, 2013. Електронний pecypc: http://www.bbc.co.uk/news/worldeurope- 22678580

5. Igliński H. Rola bezzałogowych statków powietrznych w funkcjonowaniu zwinnych łańcuchów / Hubert Igliński, Maciej Szymczak // Studia Oeconomica Posnaniensia. - № 6. - pp. 139-164

6. Worker drones: maintaining railway tracks from the air Електронний pecypc: http://www.railwaytechnology.com/features/featureworker-drones-maintaining-railway-tracks-from-the-air-4893229/6.

7. Мироненко В. К. Перспективи використання безпілотних літальних апаратів у ліквідації наслідків залізничних транспортних подій / В. К. Мироненко, П. В. Лапін, М. Д. Кацман // Залізничний транспорт України. - 2015. - № 4. C. $43-48$

8. Музикіна C. I. Аналіз безпеки руху під час перевезення небезпечних вантажів на залізничному транспорті / C. I. Музикіна // Вісник Академії митної служби України. Серія : Технічні науки. - 2014. - № 1. - С. 135-139

9. Клочков В.В. Методы прогнозирования спроса на беспилотные летательные аппараты и работы по воздушному патрулированию / В.В. Клочков, А.К. Никитова // Проблемы прогнозирования. - 2007. - № 6. - С. 144-152.

Recceived (Надійшла) 13.11.2020

Accepted for publication (Прийнята до друку) 20.01.2021

\section{Inspection and protection of railway cargoes and infrastructure using aerial drones \\ P. Lapin, M. Katsman}

Abstract. The purpose of the work is to substantiate the possibilities of air patrol of railway transport infrastructure objects with the help of aerial drones. Results. The article examines the use of drones to ensure the protection of railway infrastructure and cargoes. The authors proposed model that describe using drones on railway transport, which is based on the concept of "critical time". The content of the use of drones as a system monitoring, including a control subsystem and a subsystem of operational groups, is revealed. The model of use of unmanned aerial vehicles proposed by the authors is described, which is based on the concept of "critical time" as the difference between the time of direct intrusion into the railway infrastructure and the response time of paramilitary units of the paramilitary with the use of unmanned aerial vehicles. An example of the use of drones on a specific criminogenic section of the railway using the proposed model is disclosed. Conclusion. Improving the level of security of cargo, reducing criminal encroachments on railway infrastructure, as well as reducing damage from theft is achieved through the use of new technologies such as aerial drones. The model proposed by the authors is an accessible, simple and understandable tool for the implementation of projects for the implementation of monitoring of railway infrastructure with the help of aerial drones.

Keywords : security-free letters, critical hour, the guards of the zaliznytsia, the evil-doer, the crime-genes, the zaliznytsya, improvement and development of problems. 